\title{
TRANSPLANTATION EXPERIMENTS WITH CARIBBEAN MILLEPORA SPECIES (HYDROZOA, COELENTERATA), INCLUDING SOME ECOLOGICAL OBSERVATIONS ON GROWTH FORMS
}

\author{
by \\ WALLIE H. DE WEERDT \\ Institute of Taxonomic Zoology (Zoölogisch Museum), University of Amsterdam, The Netherlands \\ 8 \\ Caribbean Marine Biological Institute (Carmabi), Curaçao, Netherlands Antilles
}

\begin{abstract}
The historical background of the taxonomic problems in the fire-coral, Millepora, is reviewed. The growth forms of the Caribbean species: Millepora alcicornis Linnaeus, $M$. complanata Lamarck and $M$. squarrosa Lamarck are investigated in relation with environmental factors: water movement, current, light and turbidity. Several sites on Curaçao and Bonaire were visited and all forms of Millepora collected. The localities have been divided in biotopes and the relative frequencies of the growth forms in these biotopes were studied. Some relations between growth forms and environment were found: delicately branched forms appear in deeper, quieter waters, sturdy forms in sites with strong water movement, incrusting forms in turbid and also in turbulent sites. At sites with strong current Millepora corals are most abundant. The effect of transplantations on the growth forms of the three species has been studied. The transplantations caused changes in the growth form, which was most conspicuous in $M$. complanata.

It is concluded that $M$. alcicornis and $M$. complanata most likely are distinct species. However, the materials from Curaçao and Bonaire commonly identified as $M$. squarrosa do not belong to that species, but probably represent variations of $M$. complanata.
\end{abstract}

\section{RESUME}

On passe en revue les aspects historiques des problèmes taxonomiques du genre Millepora. Les différents écotypes des espèces communes de la Mer des Caraïbes ( $M$. alcicornis Linnaeus, $M$. complanata Lamarck et $M$. squarrosa Lamarck) sont étudiés par rapport aux facteurs du milieu suivants: turbulence, courant, lumière et turbidité. Plusieurs stations de Curaçao et de Bonaire ont été explorées, et l'on y a collecté les différentes formes de Millepora. Ces stations ont été classées suivant des types de biotope, et les fréquences relatives de présence des différents écotypes dans ces biotopes ont été étudiées. On a mis en évidence certaines relations entre les écotypes et le milieu: les formes délicatement ramifiées sont rencontrées dans des endroits profonds à eau peu agitée, les formes trapues dans des endroits à mode battu, les formes encroûtantes dans des endroits à turbidité et à turbulence élevées. Les Millepora abondent surtout dans les endroits à courant élevé. On a étudié l'effet de la transplantation et de l'acclimatation des écotypes des différentes espèces: ces transplantations ont entraîné les modifications les plus évidentes dans le cas des $M$. complanata.

On en arrive à la conclusion que $M$. alcicornis et $M$. complanata sont très probablement des espèces distinctes, alors que les exemplaires normalement appelés $M$. squarrosa à Curaçao et Bonaire, n'appartiennent pas à cette espèce, mais représentent vraisemblablement des variations de $M$. complanata.

\section{INTRODUCTION}

The genus Millepora Linnaeus 1758 (Milleporidae, Hydrozoa, Coelenterata) belongs to the hermatypic hydrocorals and is well represented in Recent coral reefs (e.g. Milliman, 1969; Roos, 1964, 1971; Mergner, 1971; Bak, 1975). The species delimitation within the genus is mainly based on the growth form of the corallum and geographical distribution. Five species are known from the Western Atlantic region, three of which are generally recognized in the Caribbean. The growth forms of these species are: "branching" in $M$. alcicornis, "bladed" in M. complanata and "boxwork" in $M$. squarrosa (terminology according to Stearn \& Riding, 1973). Besides such more or less clearly distinguishable forms many intermediate forms exist, of which the specific status is doubtful, and also purely incrusting forms which cannot be identified at all. Because of the high proportion of growth forms differing from the original description of the species, the question arises whether the Caribbean species are real species or represent phenotypical variations of one or two highly variable species.

To investigate how far habitat-induced modifications of the growth forms were apparent in 
the field, I visited several sites along the coast of Curaçao and Bonaire and studied the growth forms in their environment. A collection of all growth forms was made. According to differences in water movement, current and turbidity the sites have been grouped into types of biotopes. The effect of transplantations on the growth forms of the Caribbean Millepora species and of some incrusting forms is investigated. This was done to study the adaptability of the growth form, especially to different depths and to high turbidity. The fieldwork was done during a stay at the Caribbean Marine Biological Institute (Carmabi), Curaçao, from January 1976 till January 1977.

\section{REMARKS ON THE TAXONOMY OF MILLEPORA}

Many authors have dealt with the classification in Millepora, which in the past led to an almost chaotic splitting and lumping (cf. Duchassaing \& Michelotti, 1864; Hickson, 1898a; Boschma, 1948a). This taxonomic instability is not restricted to this Hydrozoan genus only. The Anthozoa, especially the Scleractinia, have also been and still are subject to taxonomic uncertainties. The main reason for this is the high variability of almost all characters used for the identification in this group of sessile marine animals, especially the growth form, which is influenced by their adaptability to various environmental circumstances (Crossland, 1928; Manten, 1960; Stoddart, 1969; Wijsman-Best, 1972, 1974).

Early students can be divided into three groups: those who called every specimen with a somewhat different appearance a new species (e.g. Duchassaing \& Michelotti, 1864), those who wanted to diminish the number of species by emphasizing the environment-induced variability (e.g. Hickson, 1898a; Wood-Jones, 1907), and those who admitted the influence of the environment on the growth form but allowed for the existence of more species than supposed by the second group (e.g. Stephenson \& Stephenson, 1933). A comprehensive survey of former studies on coral taxonomy is given by Vaughan \& Wells (1943) and Wijsman-Best (1972). In recent studies most empha- sis is given to the relation between different environmental conditions and the variation in identification characters (Roos, 1971; Wijsman-Best, 1972, 1974).

In the Milleporidae the taxonomic value of the following characters have been investigated: the texture of the surface of the corallum, the size and shape of the pores, the degree of isolation of the units formed by the dactylopores and gastropores, the distribution of the pores in the various parts of the corallum, the presence or absence of ampullae, the anatomy of the soft parts and the stinging properties (Moseley, 1877; Hickson, 1898 a \& b; Boschma, 1948 a \& b, 1949a, 1950). None of these characters proved to be of taxonomic value.

According to Boschma the growth form of the corallum, although very variable, is the only character which can be used for identification of the species. Boschma came to this conclusion after a visit to the Java Sea where he found colonies with different growth forms growing side by side (Boschma, 1948a). He also noticed that colonies in contact with each other did not unite to form one single colony, but the more slender colony was always overgrown by the more robust one. Boschma concluded from these two observations that the growth form is determined genotypically and not phenotypically, thus being species specific. In his search for other identification characters, more dependable than the growth form, Boschma found that the size and shape of the ampullae (in particular their coverings) might be of taxonomic value (Boschma, 1949a, 1950). Unfortunately his study was limited by the small number of corals with closed ampullae available. No definite statements about the taxonomic value of the ampullae could therefore be made.

The extensive studies of Boschma eventually led to a division of the genus into 13 species: M. alcicornis Linnaeus, 1758; M. braziliensis Verrill, 1868; $M$. complanata Lamarck, 1816; $M$. dichotoma Forskål, 1775; M. exaesa Forskål, 1775; M. intricata Milne Edwards, 1857; $M$. latifolia Boschma, 1948; M. murrayi Quelch, 1884; M. nitida Verrill, 1868; M. platyphylla Hemprich \& Ehrenberg, 1834; M. squarrosa Lamarck, 1816; M. tenera Boschma, 1949, and M. tuberosa Bosch- 
ma, 1966. Crossland added $M$. foveolata Crossland, 1952 (Boschma, 1948a, 1949b, 1961, 1962, 1966; Crossland, 1952).

M. alcicornis, $M$. complanata, $M$. braziliensis,
$M$. nitida and $M$. squarrosa occur in the Atlantic region (Boschma, 1948a, 1961, 1962). The other species are Indo-Pacific, although in the Red Sea only $M$. dichotoma, M. exaesa, M. platyphylla and

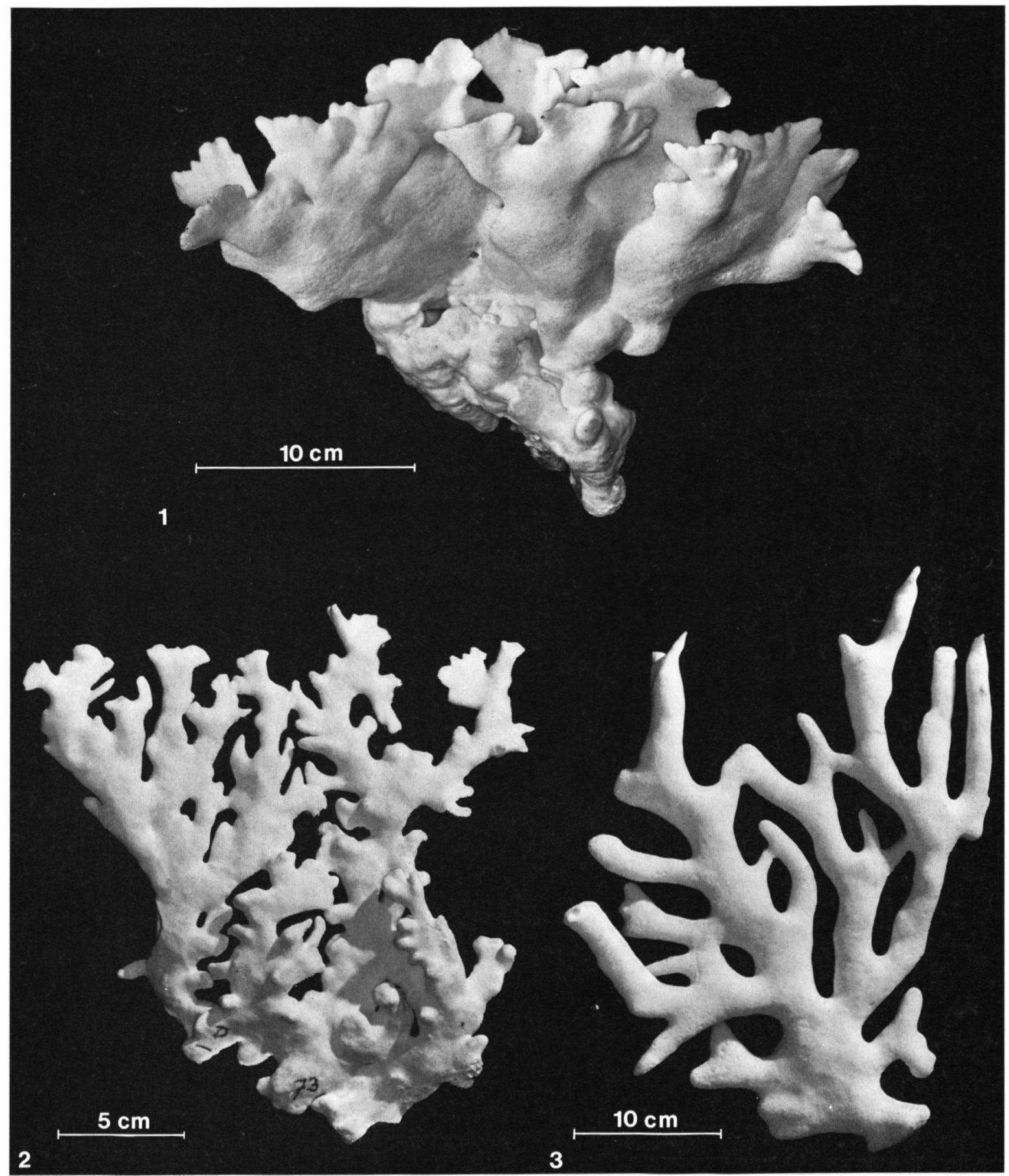

Plate I

1, Millepora alcicornis, coarse branching; 2, M. alcicornis, fine branching; 3, M. alcicornis, fine branching. 
M. tenera are found (Boschma, 1948a, 1949b, 1968).

The variation in growth form is a serious problem for a correct identification at the species level. Later studies on Millepora dealt with the depth distribution of the different growth forms (Stearn \& Riding, 1973), the variation of the growth form (Mattraw, 1969), skeletal growth (Strömgren, 1975), orientated growth (Mattraw, 1969; Velimirov, 1974), direction of growth as a part of competitive interactions (Wahle, 1980) and skeletal structure (Von Fenninger \& Flajs, 1974).
However, the effect of environmental conditions on growth forms has not yet been studied in detail in this genus and research on the taxonomic value of the above-mentioned characters has not been continued.

\section{DIAGNOSIS OF THE CARIBBEAN MILLEPORA SPECIES}

Three Caribbean Millepora species are distinguished, viz. M. alcicornis, $M$. complanata and

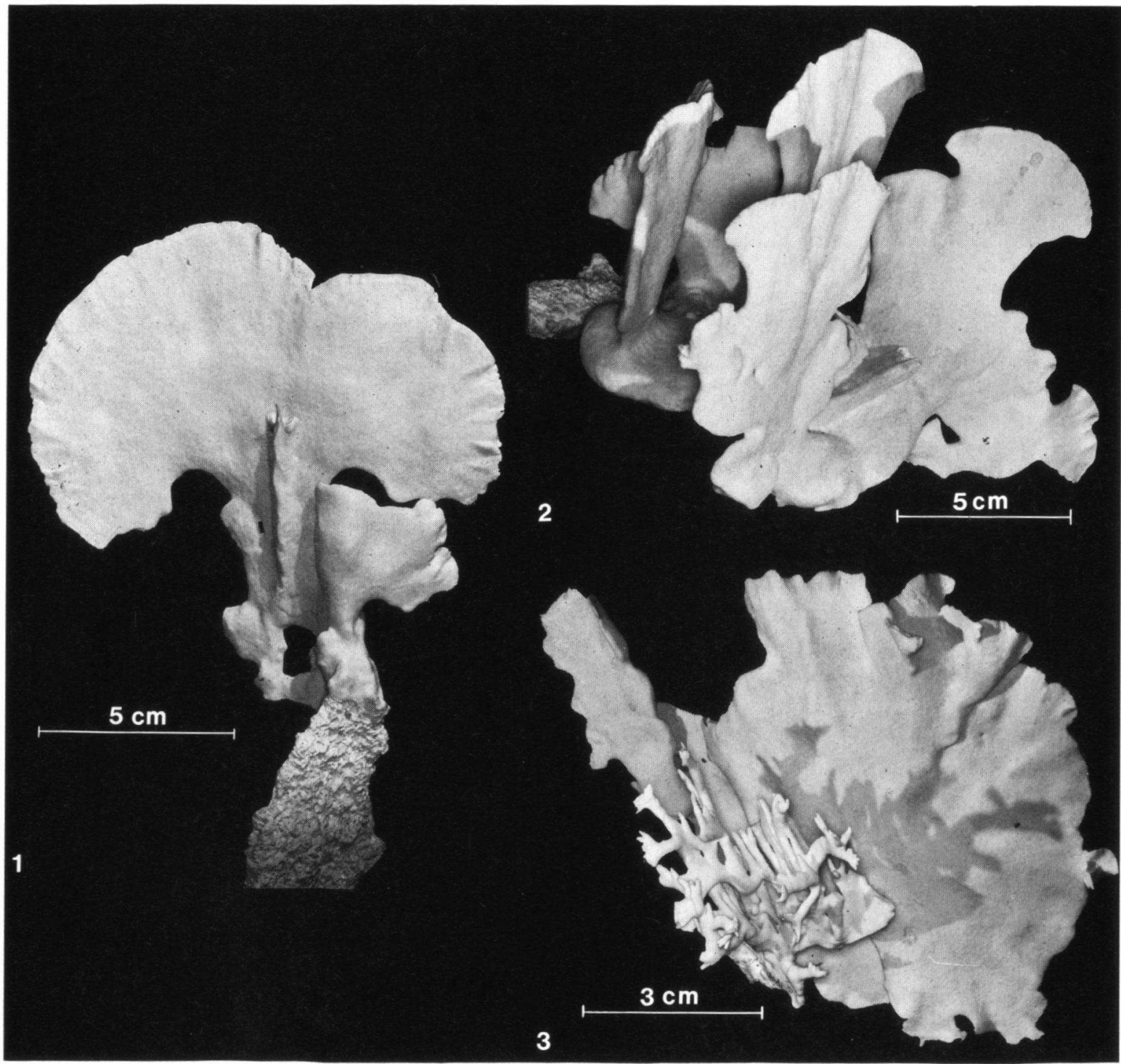

Plate II

1, Millepora complanata; 2, $M$. complanata, blades growing from a common base; 3 , two colonies, the one bladed ( $M$. com. planata), the other branching ( $M$. alcicornis), growing side by side. 
M. squarrosa. The remaining Atlantic species (M. braziliensis and $M$. nitida) are known only from Brazil. Diagnoses of the species are given below, quoted from Boschma (1948a). In the present paper, however, the species names have been avoided as much as possible. This is done to prevent misidentifications, since especially in the bladed and boxwork forms the number of colonies with an intermediate form was extremely high.

Millepora alcicornis Linnaeus, 1758. (Plate I figs. 1-3.)

"Corallum of extremely variable shape, at the growing edge divided into branches which as a rule are laterally compressed, but may be more or less finger-like. In the older parts the branches generally are united into plate-like growths or thicker compounds. Some colonies are decidedly delicately branched, others are of a very compact growth form. The surface of the corallum is even or shows shallow depressions in the centres of which the gastopores are found." (Boschma, 1948a: 18.)

Millepora complanata Lamarck, 1816. (Plate II figs. 1-3.)

"Corallum consisting of thin upstanding plates growing out from a common part. The plates are of various breadth and height, as a rule they have a truncated free edge. Surface of the corallum very smooth and even. The minute structure of the surface may be flat or may present insignificant depres. sions in the centre of which there are the gastropores." (Boschma, 1948a: 20.)

Millepora squarrosa Lamarck, 1816.

"Corallum forming upstanding thin plates with numerous lateral expansions which among each other are united to form a more or less honeycombed complex. The surface of the corallum besides the larger lateral outgrowths presents numerous crests and tubercles, giving the corallum a frilled appearance. Between the ridges and tubercles the surface of the corallum is even or showing shallow depressions each with a central gastropore." (Boschma, 1948a: 19.)

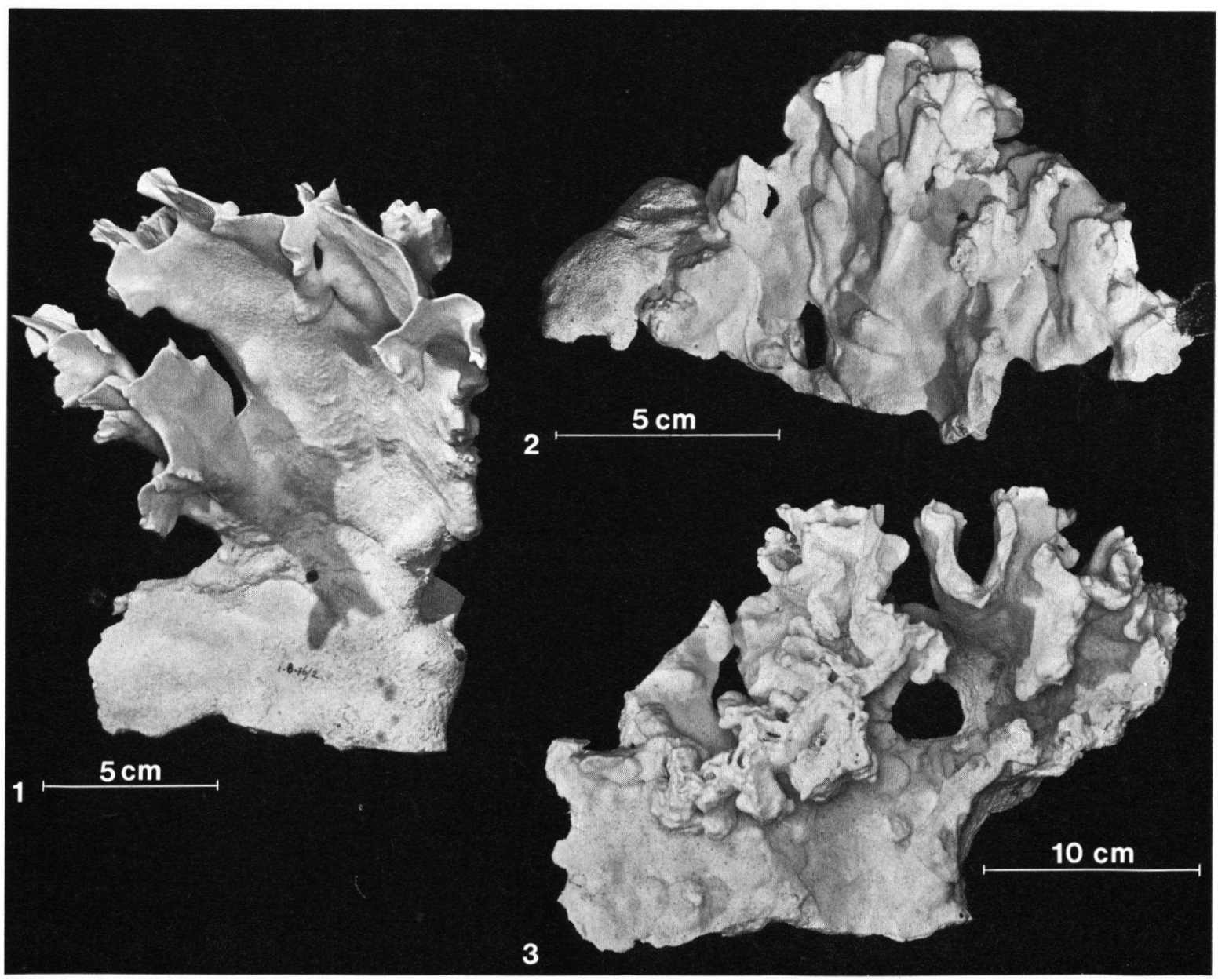

Plate III

1, Colony of Millepora with a growth form intermediate between Millepora complanata and $M$. "squarrosa" (thin bladed boxwork); 2, M. "squarrosa", thick bladed boxwork; 3, M. "squarrosa", dwarf form. 
In plate III figs. $2 \& 3$, two colonies generally considered to be $M$. squarrosa are shown. However, they may represent growth forms of $M$. complanata, instead of being the real $M$. squarrosa (see Conclusions and Discussion section in the present paper).

In plate IV figs. $1 \& 2$, two incrusting forms, one incrusting a head of dead coral, the other incrusting a gorgonian, are shown.

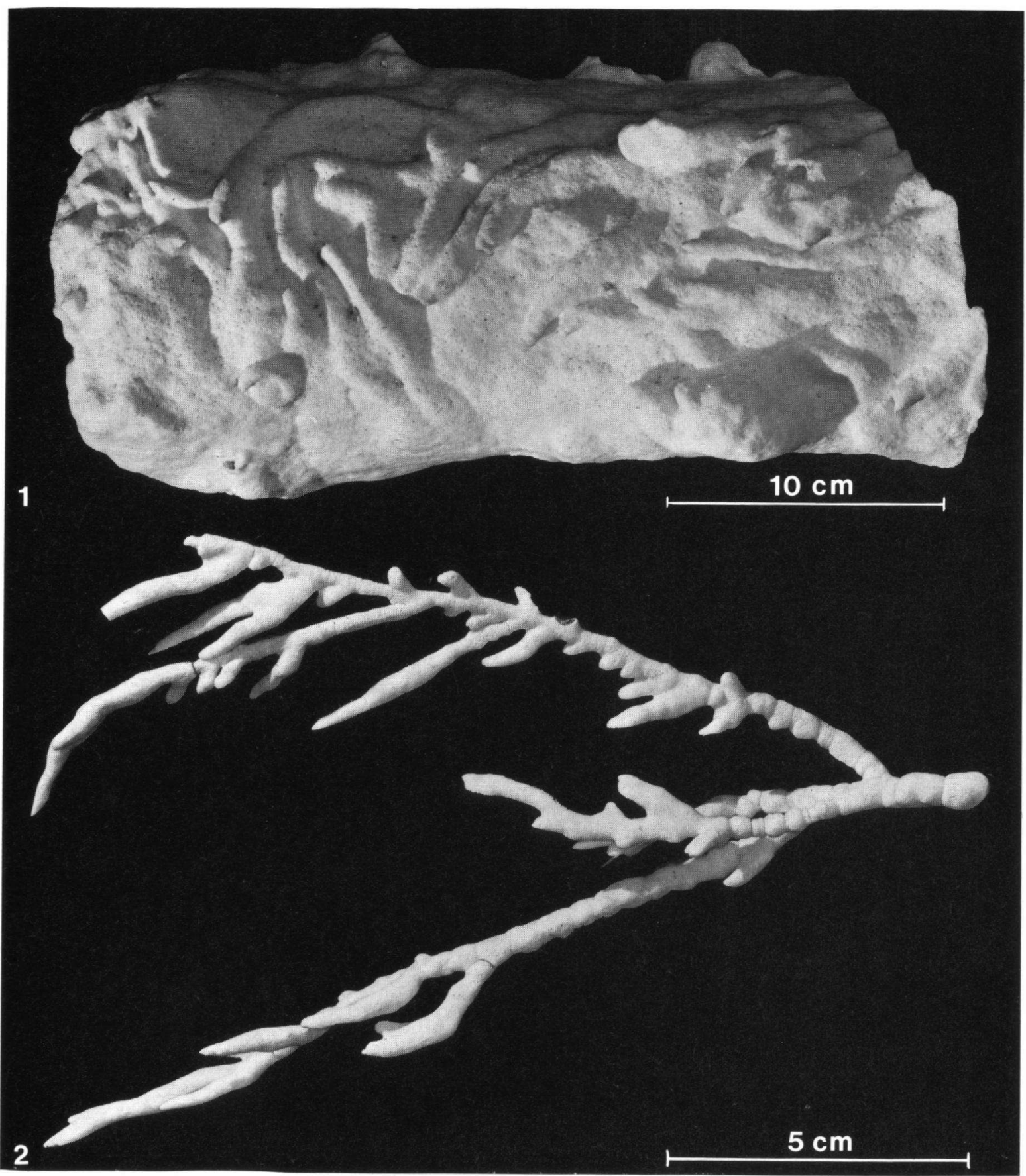

Plate IV

1, Colony of Millepora, incrusting dead coral; 2, colony of Millepora, incrusting a gorgonian. 


\section{MATERIALS AND METHODS}

\section{Classification of the growth forms}

To study the growth forms of Millepora in the different types of biotopes, a rough classification of the growth forms was made. The branching form has been subdivided into coarse branching and fine branching. The boxwork form has been subdivided into thick bladed and thin bladed boxwork. Furthermore, a dwarf form of boxwork could be recognized with a remarkable compactness and sturdiness, often growing from a large incrusting base. All growth forms encountered could finally be grouped according to the following seven growth patterns: incrusting (plate IV figs. $1 \& 2$ ), coarse branching (plate I fig. 1 ), fine branching (plate I figs. $2 \& 3$ ), bladed (plate II figs. 1-3), thin bladed boxwork (plate III fig. 1 ), thick bladed boxwork (plate III fig. 2) and boxwork dwarf form (plate III fig. 3 ). A collection was made of all growth forms (ca. 250 specimens).

\section{Classification of the biotopes and abundances}

Twenty-two localities on Curaçao and Bonaire were visited and the distribution of the growth forms along several depth intervals recorded. For the frequency of growth forms an arbitrary scale was used, viz. high abundance, mean abundance, low abundance, absent. Some localities could only be visited occasionally. To get a general impression of the relative abundances of growth forms in the time available this method was preferred. The localities were grouped into nine biotopes according to three ecological parameters, viz. water movement (turbulence), current and turbidity. The biotopes were subdivided into four depth intervals, viz. 0-2 $\mathrm{m}$ (surf zone), 2-10 m (shelf), 10-15 m (drop-off), and 15-45 m (slope).

\section{Transplantation experiments}

The transplantation experiments were carried out at two different sites (stations $a$ and $b$ ) near the Caribbean Marine Biological Institute (fig. 1).

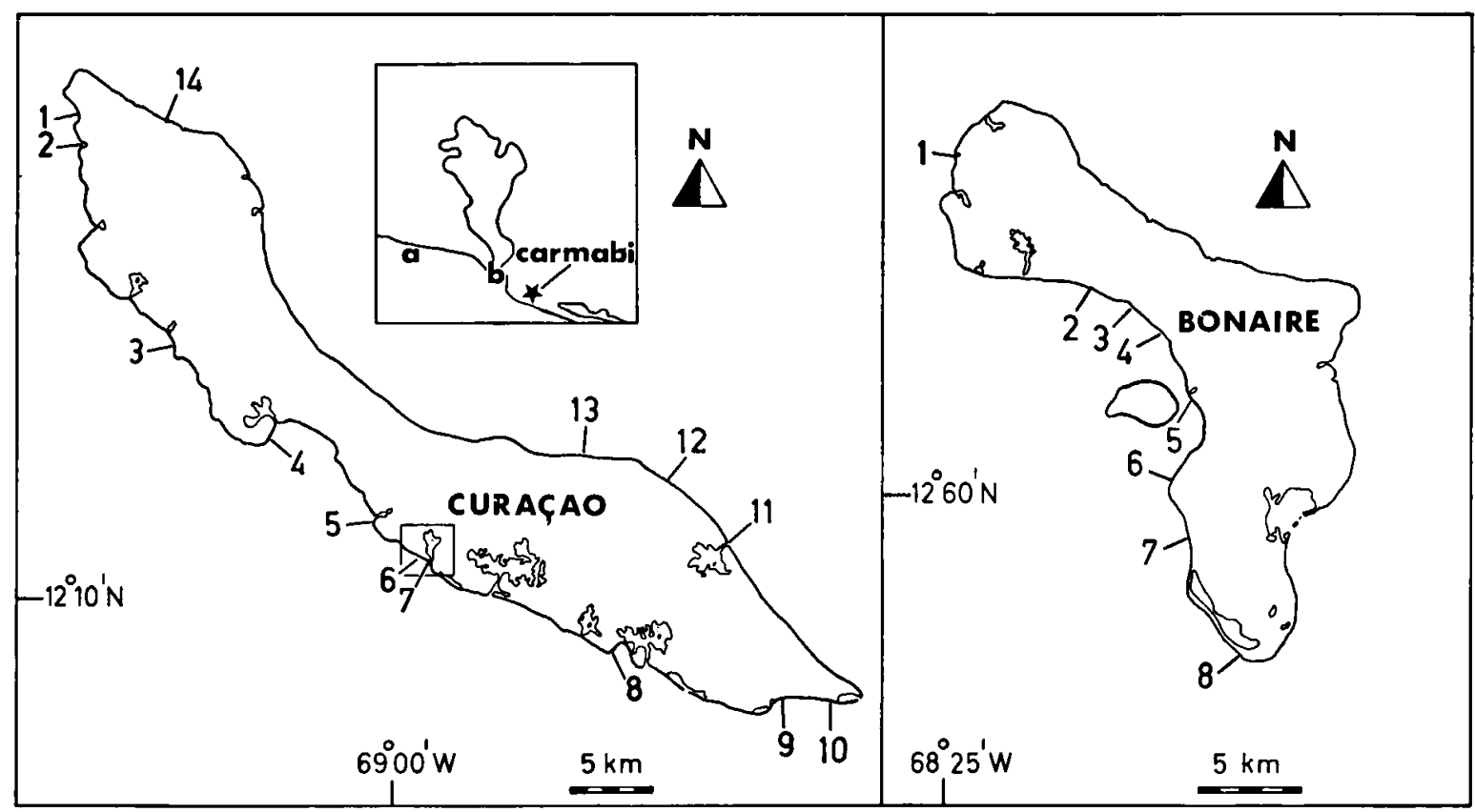

Fig. 1. Localities visited on Curaçao (C) and Bonaire (B), including the experimental stations $a$ and $b$ (inset). $\mathrm{C} 1=$ Playa Kalki, C2 = Playa Abao, C3 = Playa Mansaliña, C4 = Cape St. Marie, C5 = St. Michiels Bay, C6 = $500 \mathrm{~m}$ NW of Piscadera Bay, C7 = Piscadera Bay, entrance, C8 $=$ Lijhoek, $C 9=5 \mathrm{~km} \mathrm{~W}$ of Oostpunt, C10 $=3 \mathrm{~km} \mathrm{~W}$ of Oostpunt, C11 = Boca St. Joris, C12 = Ronde Klip, C13 = Boca Santu Pretu, C14 = Boca Tabla. B1 = Playa Funchi, B2 = Karpata, B3 = Barcadera, B4 = Santa Barbara, B5 $=2 \mathrm{~km} \mathrm{~N}$ of Kralendijk, B6 = Bachelor's Beach, B7 = Blauwe Pan, B8 = Rode Pan. 


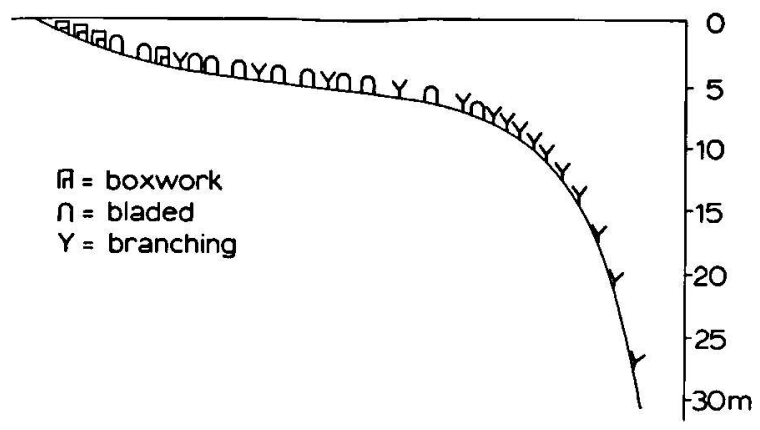

Fig. 2. Profile of station a with bathymetric zonation of the growth forms representing the three Caribbean Millepora species. Branching $=M$. alcicornis, bladed $=M$. complanata, boxwork = M. "squarrosa".

Colonies were used with a growth form classically considered characteristic of the species and incrusting colonies, on both gorgonians and dead coral, were used as well. According to the literature the growth forms which should represent the three Caribbean Millepora species show a bathymetric zonation (Stearn \& Riding, 1973).
This was apparent at station a (fig. 2). The boxwork form occurred in the surf zone down to about $3 \mathrm{~m}$. The bladed form occurred from about $2 \mathrm{~m}$ down to about $12 \mathrm{~m}$. Its greatest abundance was on the shelf at about $5 \mathrm{~m}$. The branching form appeared to have the greatest depth range. It occurred from about $3 \mathrm{~m}$ down to about $45 \mathrm{~m}$. Its greatest abundance was near the drop-off at 12 to $15 \mathrm{~m}$. The depth with greatest abundance of one of these forms will be called "optimum depth" in the sequel. In the incrusting forms a bathymetric zonation was not apparent. However, purely incrusting forms were difficult to find, for mostly they have some little outgrowths. In the upper surf zone purely incrusting forms were not found at station $a$.

At station $a$ the effect of transplantations to a different depth on the growth form was studied. Colonies of each growth form were taken from their optimum depth and transplanted to the optimum depth of the two other growth forms. The transplantation experiments thus have been carried

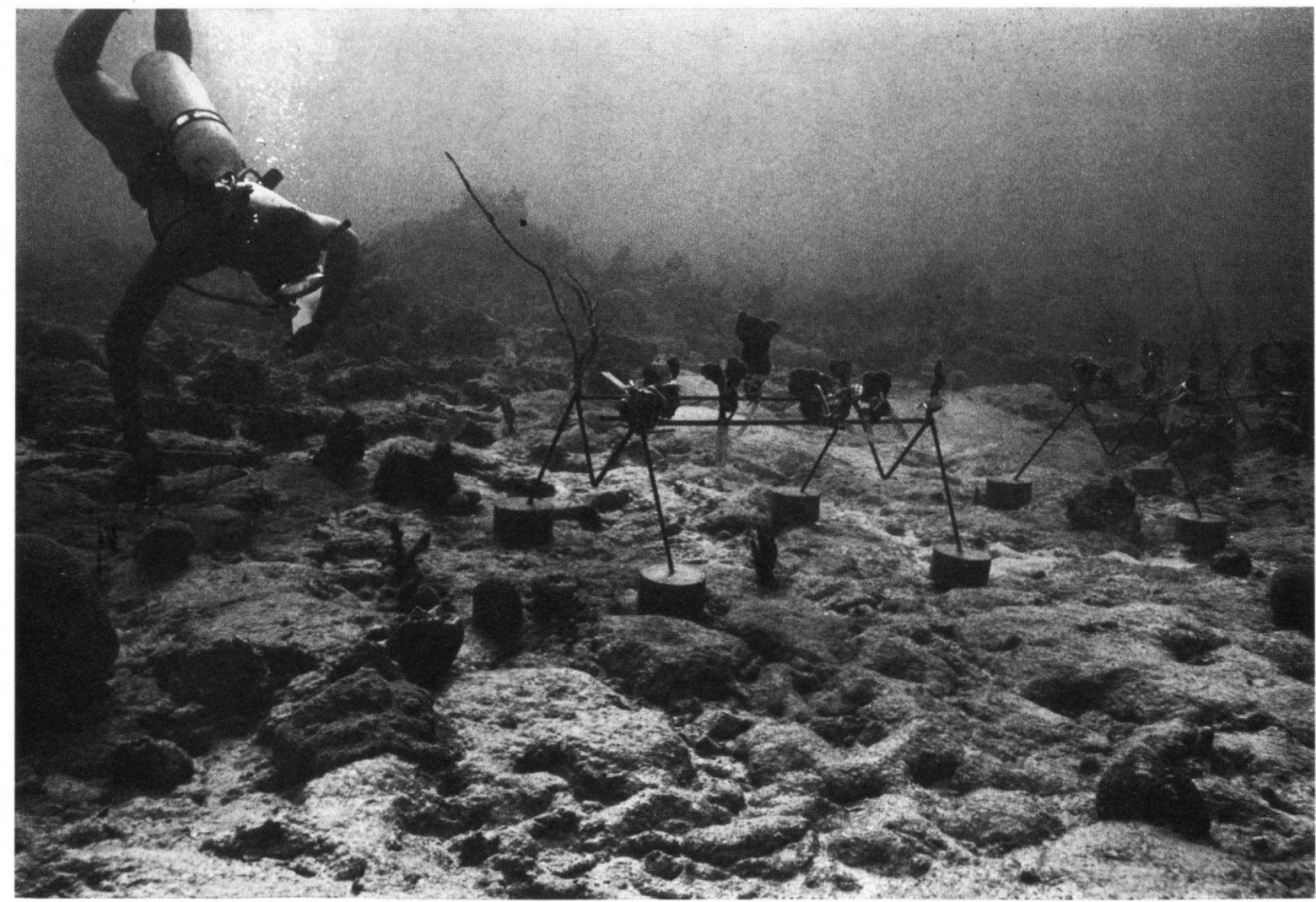

Fig. 3. Iron frames with pins to which transplanted colonies of Millepora are fixed with plastic rope. 


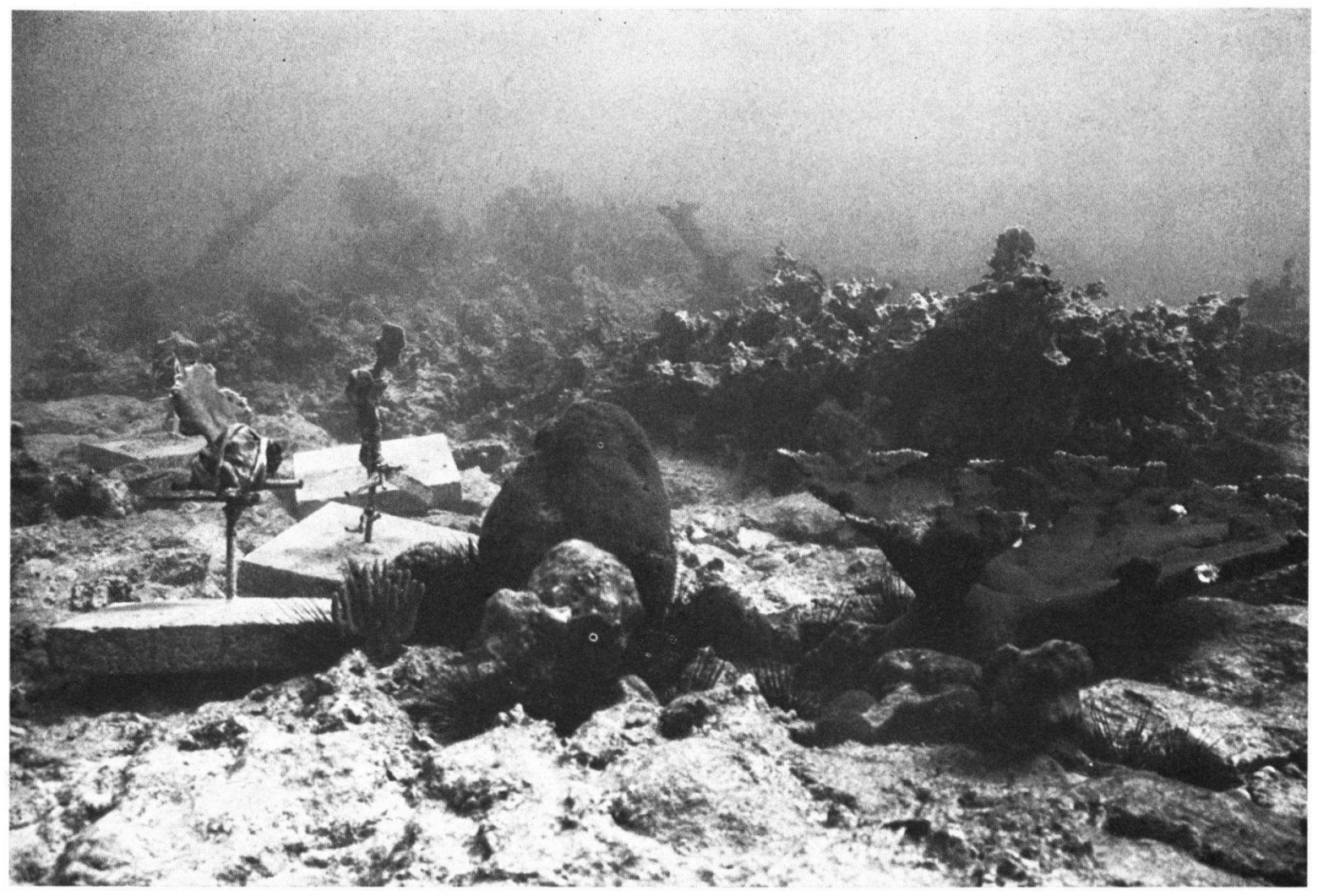

Fig. 4. Concrete blocks each with one colony. They were used in the surf zone.

out at three different depths: 1,5 and $15 \mathrm{~m}$. Although the incrusting forms had no optimum depth, for convenience the same depths were used (except for $1 \mathrm{~m}$ ). Control colonies remained at their original depth but were handled in the same way as the transplanted colonies.

At station $b$ the effect of high turbidity was studied. Except for some incrusting Millepora colonies no corals were growing at this site. Corals transplanted to station $b$ (depth $5 \mathrm{~m}$ ) originated from the nearby reef (ca. $20 \mathrm{~m} \mathrm{NW}$ of the entrance of Piscadera Bay). Colonies of more or less the same size were used (height $10-15 \mathrm{~cm}$ ). After collecting they were individually transported under water to their new growing place. The colonies were in their original position and orientation fixed with plastic rope to metal pins, attached to iron frames. Each frame carried ten of these pins (fig. 3). A more heavy construction was needed in the surf zone. Here concrete blocks were used, carrying one colony each (fig. 4). Immediately after the transplantation the colonies were photographed in situ together with a measuring scale. An underwater Nikonos II camera with a $28 \mathrm{~mm}$ lens provided with a close-up lens was used. During the experiments the colonies were photographed from the same position each third month. At the end of the experiments they were removed from the pins and taken out of the water. They were immersed during 24 hours in undiluted household bleach (Chlorox) and after this rinsed with fresh water for about two hours. The colonies were dried in the open air for about two days. This treatment, which completely removed the living tissue, was necessary for the investigation of the skeleton structure. The duration of the experiments was nine months. All underwater work was done using SCUBA.

\section{Localities studied}

Short descriptions of the nine biotopes recognized are given below. The localities in Bonaire (B) and Curaçao (C), including the experimental stations, are shown in fig. 1. 
B i o t o pe I (localities: C11a (reef outside the entrance), C12, C13, C14).

Water movement: extremely strong wave action.

Current: absent in the time the localities were visited.

Turbidity: low.

Additional information: all these localities are situated at the windward side of Curaçao, where the water movement is extremely strong. Except for a few days a year, when the permanent northeastern trade wind decreases in velocity, the area is unaccessible for divers. Remarkable is the great abundance of the alga Sargassum platycarpum and the relatively low abundance of corals at the shelf.

B i o t o pe II (locality: C11b (entrance of a lagoon)).

Water movement: extremely strong.

Current: absent in the time the locality was visited.

Turbidity: high.

Additional information: at this site a "bottle-neck" situation exists, causing a strong water movement to and from the narrow entrance of the inner bay. Sargassum platycarpum is very abundant and coral growth scarce. Turbidity is much higher than at the reef outside the entrance, due to sediments from the inner bay.

B i o t o pe III (localities: C4, C8, C9, C10)

Water movement: strong.

Current: not permanent, sometimes rather strong.

Turbidity: very low.

Additional information: this biotope represents the "open cliff" situation which could only be studied in Curaçao. The sites are, because of their exposition, the most turbulent spots of the south (leeward) coast of the island. The coverage of living corals and gorgonians amounts to nearly $100 \%$.

B i ot ope IV (localities: C1, B1)

Water movement: moderate, a surf zone exists.

Current: a permanent NW current, which sometimes is very strong.

Turbidity: moderate.

Additional information: Noteworthy in both sites is the high abundance of reef building Millepora corals, which seem to have their optimum habitat here.

B i o t o pe V (localities: B2, B3, B4, B5, B6, B7).

Water movement: moderate, a surf zone exists.

Current: absent.

Turbidity: very low.

Additional information: diversity and abundance of corals is remarkably high.

B i o to pe VI (locality: B8).

Water movement: moderate, surf sometimes strong.

Current: absent.

Turbidity: high.

Additional information: the reef consists of channels and ridges with much sediment and coral debris; living corals are rare.

B i o t o p e VII (localities: C2a (cliffs at both sides of the bay), C5, C6 = station a).

Water movement: moderate, a surf zone exists.

Current: moderate.

Turbidity: moderate.
B i o t o p e VIII (localities: C2b (bay), C3)

Water movement: low.

Current: absent.

Turbidity: high.

Additional information: sandy bays without surf and with rather high turbidity; at the shelf coral growth is rare but becomes more abundant near the drop-off and along the slope.

B i o to pe IX (locality: C7 = station $b$ ).

Water movement: absent.

Current: absent.

Turbidity: extremely high.

Additional information: no corals are growing at this site, except for some incrusting Millepora; the high turbidity is due to sediments from the inner bay, where a mangrove zone exists.

\section{RESULTS}

Growth forms of Millepora and environmental factors

In fig. 5 the relative abundance of the growth forms in the various biotopes is shown. The biotopes are arranged according to increasing turbulence, the growth forms according to increasing abundance at greater depths.

The quantity of Millepora and the variety of growth forms was lowest in biotope I. The scarce growth of corals is partly due to the strong water movement, and partly to the absence of herbivores, (Bak, 1975). The absence of herbivores, which allows the high abundance of Sargassum platycarpum seems to be the main reason for the low density of Millepora, for in other biotopes with strong water movement (especially biotope III), they were more abundant. In another extreme environment, the bottle-neck situation in a narrow channel (biotope II) and in the upper surf zone of the most turbulent localities the dwarf form of boxwork was found. This form, often growing from a large incrusting base, is quite capable of resisting strong water movement.

The diversity of growth forms was highest in biotopes III and V. The localities of both biotopes were characterized by a remarkable rich coral growth. This may be explained as follows. The two biotopes have two characters in common: (1) extremely transparent water; (2) no destruction caused by people. In Bonaire gathering of corals and spearfishing have been forbidden earlier than 

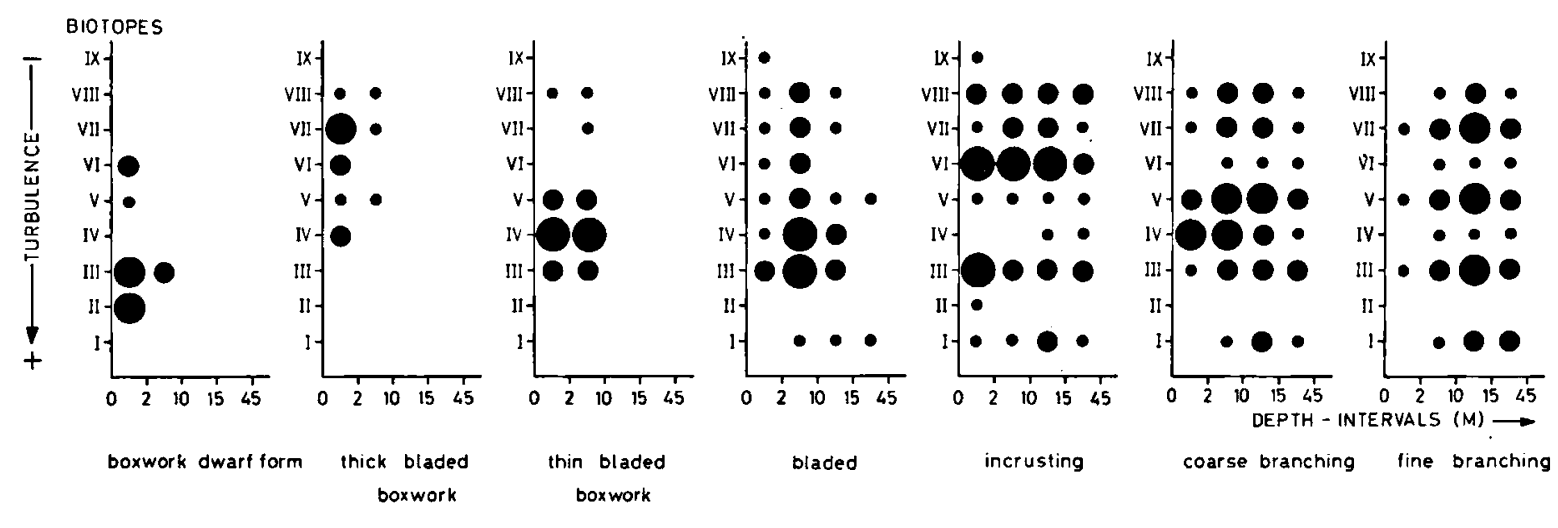

- =low abundance

= intermediate abundance

$=$ high abundance

Fig. 5. Relative abundance of the growth forms of Millepora in the nine biotopes distinguished (see text). Biotopes are arranged according to decreasing turbulence, growth forms according to increasing abundance at greater depths.

in Curaçao (Curaçao: 1976). As a whole the Bonaire localities are much richer in coral growth and variety of fish than those in Curaçao. The localities of biotope III in Curaçao, however, are among the less accessible spots at the island's south coast. At these sites coral growth was also relatively abundant, characterized for instance by the presence of species of Antipathes ("black coral"), which are almost completely lacking in the other localities. Playa Kalki (C1) and Playa Funchi (B1) are characterized by a co-dominance at the shelf of the bladed, thin bladed boxwork and coarse branching growth forms, all occurring in very great quantities. As a whole the amount of different growth forms of Millepora colonies and their abundances are remarkably high in these localities. Only in one instance this co-existence can be explained by differences in micro-habitat. The bladed forms grow perpendicular to the current (cf. the observation by Velimirov, 1974, for the Indo-Pacific species, $M$. dichotoma). The space behind the blades will thus form a sort of "stream shade" allowing growth of more delicate forms. Abundant growth of branching forms "behind" the sturdy, bladed forms was frequently observed. In plate II fig. 3, two colonies with different growth forms, the one bladed, the other fine branched are shown growing side by side.

Current seems to be a favourable abiotic factor for Millepora corals, in agreement with Mergner
(1977) who called $M$. complanata extremely rheophilic. When turbulence is low little damage will be suffered by the mechanical forces of the water. There is no need to develop a very sturdy growth form, so all calcium deposited will contribute to a growth in height and breadth instead of growth in thickness. The current also ensures a permanent food supply which enables a luxurous growth. In the biotopes VI-IX a decreasing variety in growth forms and in abundance was observed. In biotope VI the zonation of the growth forms as mentioned earlier was obvious. In these localities (biotopes VI-IX, with higher turbidity) more incrusting forms were found than in biotopes with clearer water, especially in the localities of biotopes VIII and IX where turbidity was very high. From this one might conclude that Millepora is quite capable of surviving non-optimal conditions by remaining incrusting. This was already mentioned by Crossland (1928).

\section{Transplantation experiments}

In table I the number of colonies involved in the transplantation experiments and the mortality of the colonies are given. Mortality was caused by breaking off, especially by destruction in the surf zone, and by algae overgrowth. To obtain a general view all forms were involved in these experiments but in some cases sample sizes are 


\section{TABLE I}

Number of colonies transplanted to different depths at station $a$ and to station $b$. The growth forms branching, bladed and boxwork represent the species Millepora alcicornis, $M$. complanata and $M$. "squarrosa", respectively (see text).

\begin{tabular}{|c|c|c|c|c|c|c|c|c|c|}
\hline \multirow[t]{4}{*}{ growth form } & \multirow{4}{*}{$\begin{array}{l}\text { depth of } \\
\text { growth }\end{array}$} & \multicolumn{5}{|c|}{ depth of transplantation } & total number of & \multicolumn{2}{|c|}{ mortality } \\
\hline & & \multirow{2}{*}{\multicolumn{2}{|c|}{$1 \mathrm{~m}$}} & station a & & station $b$ & & & \\
\hline & & & & $5 \mathrm{~m}$ & $15 \mathrm{~m}$ & $5 \mathrm{~m}$ & & & \\
\hline & & \multicolumn{5}{|c|}{$\begin{array}{l}\text { number of colonies transplanted } \\
\text { (died colonies) }\end{array}$} & & number & $\%$ \\
\hline branching & 15 & 5 & (1) & $2(0)$ & $2(0)$ & $2(0)$ & 11 & 1 & 9.9 \\
\hline bladed & 5 & 30 & (7) & $2(0)$ & $8(1)$ & $2(0)$ & 42 & 8 & 19 \\
\hline boxwork & 1 & 2 & (0) & $15(3)$ & $2(0)$ & $2(0)$ & 21 & 3 & 14.3 \\
\hline IC & 5 & 2 & (2) & $2(0)$ & $2(0)$ & $2(0)$ & 8 & 2 & 25 \\
\hline IC & 15 & 2 & (2) & $2(0)$ & $2(0)$ & $2(1)$ & 8 & 3 & 37.5 \\
\hline IG & 5 & 2 & (1) & $2(1)$ & $2(1)$ & $2(0)$ & 8 & 3 & 37.5 \\
\hline IG & 15 & 2 & (2) & $2(1)$ & $2(1)$ & 一 & 6 & 3 & 50 \\
\hline \multirow[t]{2}{*}{ IC (stat. $\left.b)^{*}\right)$} & 5 & & 一 & - & - & $2(1)$ & 2 & 1 & 50 \\
\hline & & 45 & (15) & $27(5)$ & $20(3)$ & $14(2)$ & 106 & 24 & 22.6 \\
\hline
\end{tabular}

IC = incrusting dead coral; IG = incrusting gorgonians.

*) Incrusting dead coral in the entrance of the Piscadera Bay (station $b$ ); used as control colonies of this site.

rather small. Only the growth forms bladed and boxwork received special emphasis and were transplanted to each other's optimum depths in larger numbers.

\section{Station a}

Branching forms. - The four surviving colonies of this growth form, transplanted from $15 \mathrm{~m}$ to the surf zone $(1 \mathrm{~m})$ adapted themselves very well to the new depth. At the end of the experiment their growth form was much more sturdy than at the beginning and also in comparison with the control colonies. In plate $\mathrm{V}$ figs. 1 and 2 the growth of one colony, transplanted to the surf zone is shown. Two colonies, transplanted to $5 \mathrm{~m}$ also became more sturdy, but in a lesser degree than those transplanted to the surf zone.

Bladed forms. - The 30 colonies transplanted from $5 \mathrm{~m}$ to the surf zone showed a very fast growth in comparison with the colonies transplanted to $15 \mathrm{~m}$ and the control colonies. Because of their growth form it was possible to make some rough measurements of the two-dimensional growth of some colonies. This was done by using the photographs and transparent paper on which the outlines of the colonies were drawn. In fig. 6 the outline of one colony, transplanted to $15 \mathrm{~m}$ is shown. The black zone represents the growth after 260 days. The results of the measurements are shown in table II. Growth is expressed in square $\mathrm{mm} \cdot \mathrm{cm}^{-1}$ growing edge per month.

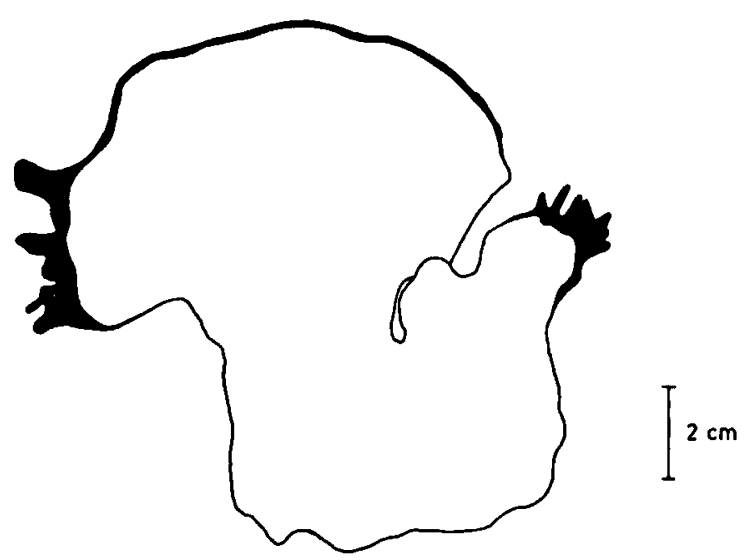

Fig. 6. Growth (black edges) of a bladed colony, transplanted from $5 \mathrm{~m}$ to $15 \mathrm{~m}$ (after 260 days). 
TABLE II

Growth of individual bladed colonies, transplanted to different depths at station $a$.

\begin{tabular}{|c|c|c|c|}
\hline $\begin{array}{l}\text { depth of } \\
\text { growth }\end{array}$ & $\begin{array}{l}\text { depth of } \\
\text { transplantation }\end{array}$ & $\begin{array}{l}\text { total length } \\
\text { growing edges }\end{array}$ & $\begin{array}{l}\text { mean growth of the different } \\
\text { growing edges }\end{array}$ \\
\hline (m) & $(\mathrm{m})$ & $(\mathrm{cm})$ & ( $\mathrm{mm}^{2} . \mathrm{cm}^{-1}$ growing edge/month) \\
\hline 5 & 1 & 1.8 & 12 \\
\hline 5 & 1 & 6 & 18 \\
\hline 5 & 1 & 13.7 & 11 \\
\hline 5 & 1 & 4.6 & 18 \\
\hline 5 & 1 & 3.8 & 12 \\
\hline 5 & 5 & 2 & 6 \\
\hline 5 & 5 & 17.3 & 6 \\
\hline 5 & 15 & 17 & 3 \\
\hline 5 & 15 & 19 & 3 \\
\hline
\end{tabular}

The growth rates of the colonies transplanted to different depths show marked differences. It is known that the growth rate of hermatypic corals is highly dependent on the light available because of their symbiosis with zooxanthellae (Goreau, 1959, 1963; Goreau \& Goreau, 1959). The amount of light decreases with increasing depth and an inverse relation between the growth rate of some coral species and depth was reported by these authors. The Milleporidae also have zooxanthellae in their living tissues (Boschma, 1925; De Kruijf, 1975) and the amount of light available is known to influence their growth rate (Goreau, 1963; Strömgren, 1975). The results of the measurements of this study, which indicate that growth rate was highest in the colonies transplanted to $1 \mathrm{~m}$ and lowest in the colonies transplanted to $15 \mathrm{~m}$, are in agreement with this. In two colonies, transplanted to the surf zone lateral outgrowths began to develop. The growth of one of these colonies is shown in plate VI figs. 1-4.

Most interesting are the colonies transplanted to $15 \mathrm{~m}$. Five of the eight colonies developed delicate, branchelike outgrowths. In plate $\mathrm{V}$ figs. 3 and 4 the growth of one colony is shown.

Boxwork forms. - The colonies with this growth form were less able to adapt to the new depths. The colonies transplanted from $1 \mathrm{~m}$ to both 5 and $15 \mathrm{~m}$ did hardly show any growth. See plate VII figs. 1 and 2 for the growth of one colony, transplanted to $5 \mathrm{~m}$. However, some growth can be observed in this colony. The lateral outgrowths seem to disappear and the colony becomes more bladed.

Incrusting forms. - Only 5 of the 24 colonies, transplanted to various depths, showed any growth. Eleven colonies died, 13 colonies were still alive at the end of the experiments but 8 of them showed no growth. Death rate was highest in the surf zone and among the growth forms incrusting gorgonians. In plate VII figs. 3 and 4 the growth of an incrusting colony on a coral head, used as control colony at $5 \mathrm{~m}$ is shown. It is clear that this incrusting form was the incrusting initial phase of four bladed outgrowths. The same happened with a colony growing at $5 \mathrm{~m}$, transplanted to $15 \mathrm{~m}$. Delicate outgrowths developed in both control colonies of $15 \mathrm{~m}$ as well. One colony however was not really incrusting at the start; some branched outgrowths already existed. Some delicate outgrowths developed in a gorgonian incrusting colony from $15 \mathrm{~m}$, transplanted to $5 \mathrm{~m}$ and also in one control colony from $5 \mathrm{~m}$.

\section{Station $b$}

Most colonies transplanted to station $b$ suffered from sedimentation and algal growth, but they were still alive (the polyps being active) at the end of the experiments. Growth could be observed in the two colonies of the bladed form and in three incrusting forms. The boxwork colonies only partly recovered from algal overgrowth. One colony formed ampullae, which might be a survival mechanism (see plate VIII figs. 1 and 2 ). 


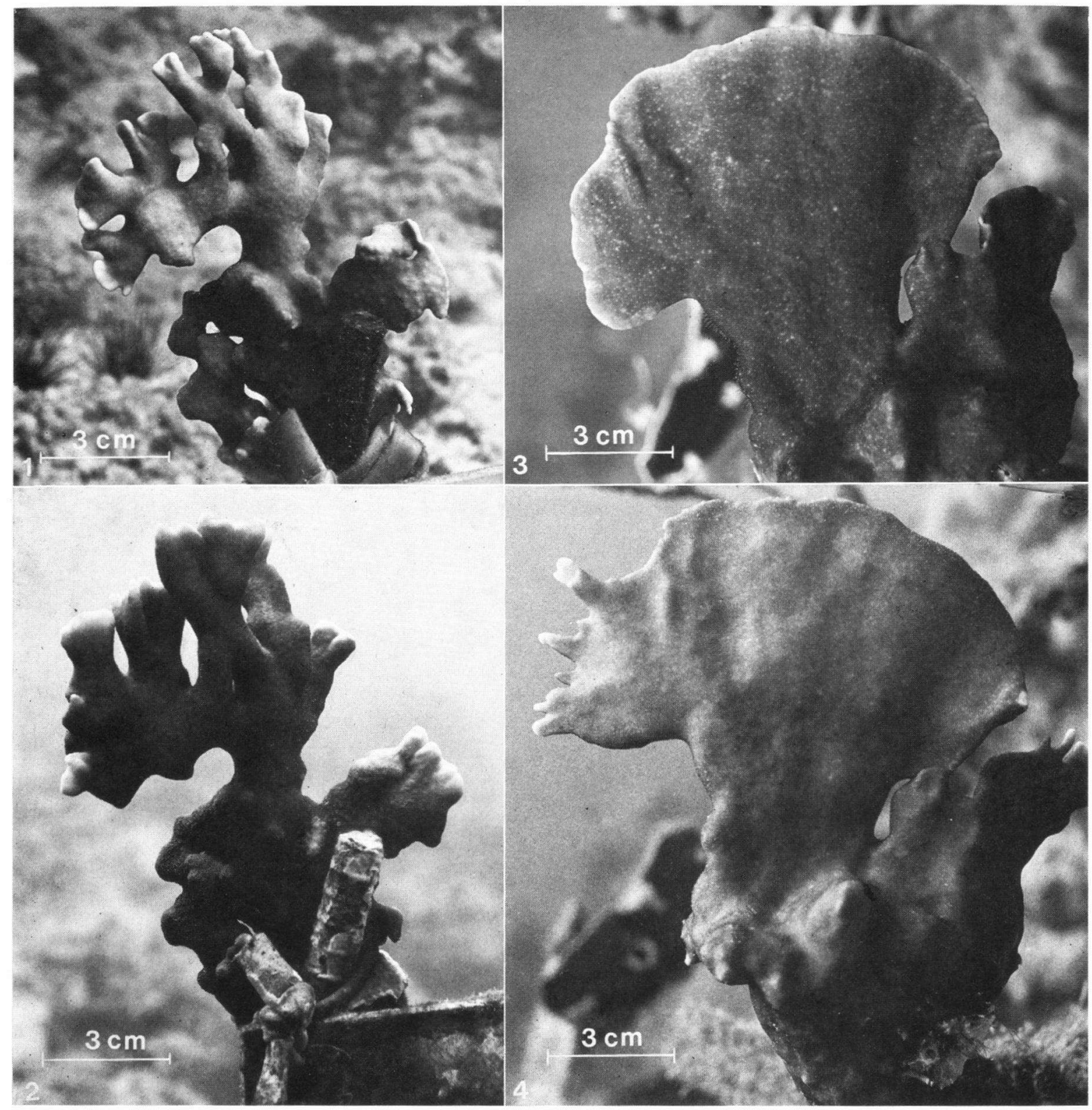

\section{Plate V}

1, Branching colony, transplanted from $15 \mathrm{~m}$ to $1 \mathrm{~m}$, date: 3 June 1976; 2, same colony, date: 8 December 1976; 3, bladed colony, transplanted from $5 \mathrm{~m}$ to $15 \mathrm{~m}$, date: 13 April 1976; 4, same colony, date: 10 December 1976.

In one colony incrusting dead coral from $5 \mathrm{~m}$ some delicate outgrowths developed. These results seem to indicate that Millepora is quite capable to survive in turbid conditions.

\section{CONCLUSIONS AND DISCUSSION}

Some relations between the growth form in Millepora and the environment were found in this study: finely branched forms appear in deeper, quieter waters, sturdy forms in more turbulent waters, incrusting forms in turbid places as well as in extremely turbulent places. These adaptations in Millepora to environmental factors, especially water movement and light conditions have been described in scleractinian coral species as well (Yonge, 1963; Roos, 1964, 1967, 1971; 


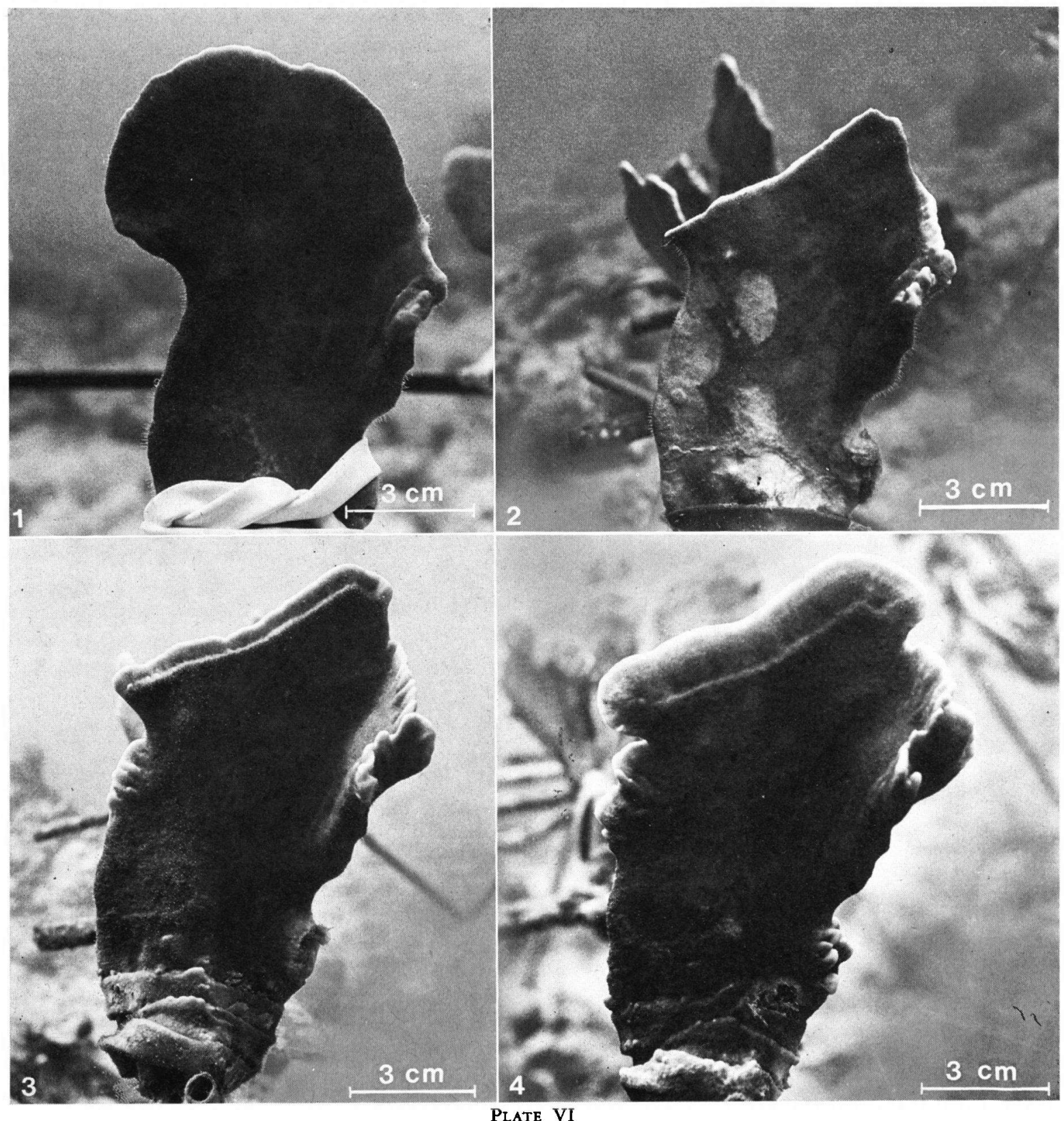

1, Bladed colony, transplanted from $5 \mathrm{~m}$ to $1 \mathrm{~m}$, date: 4 May 1976; 2, same colony, date: 9 June 1976; 3, same colony, date: 25 August 1976; 4, same colony, date: 9 December 1976.

Milliman, 1973). In the sites with strong current the abundance and co-existence of several growth forms of Millepora was highest, from which can be concluded that Millepora is extremely rheophilic.

The coexistence of different growth forms, however, is only to a certain extent explained by differences in ecological conditions. The various growth forms have wide and overlapping ecological amplitudes, which appears most clearly in optimal biotopes for Millepora. In contrast with these observations are the results of the transplantation experiments. Some bladed colonies started to resemble boxwork, when transplanted to the optimum depth of boxwork and most colonies transplanted to the optimum depth of the 


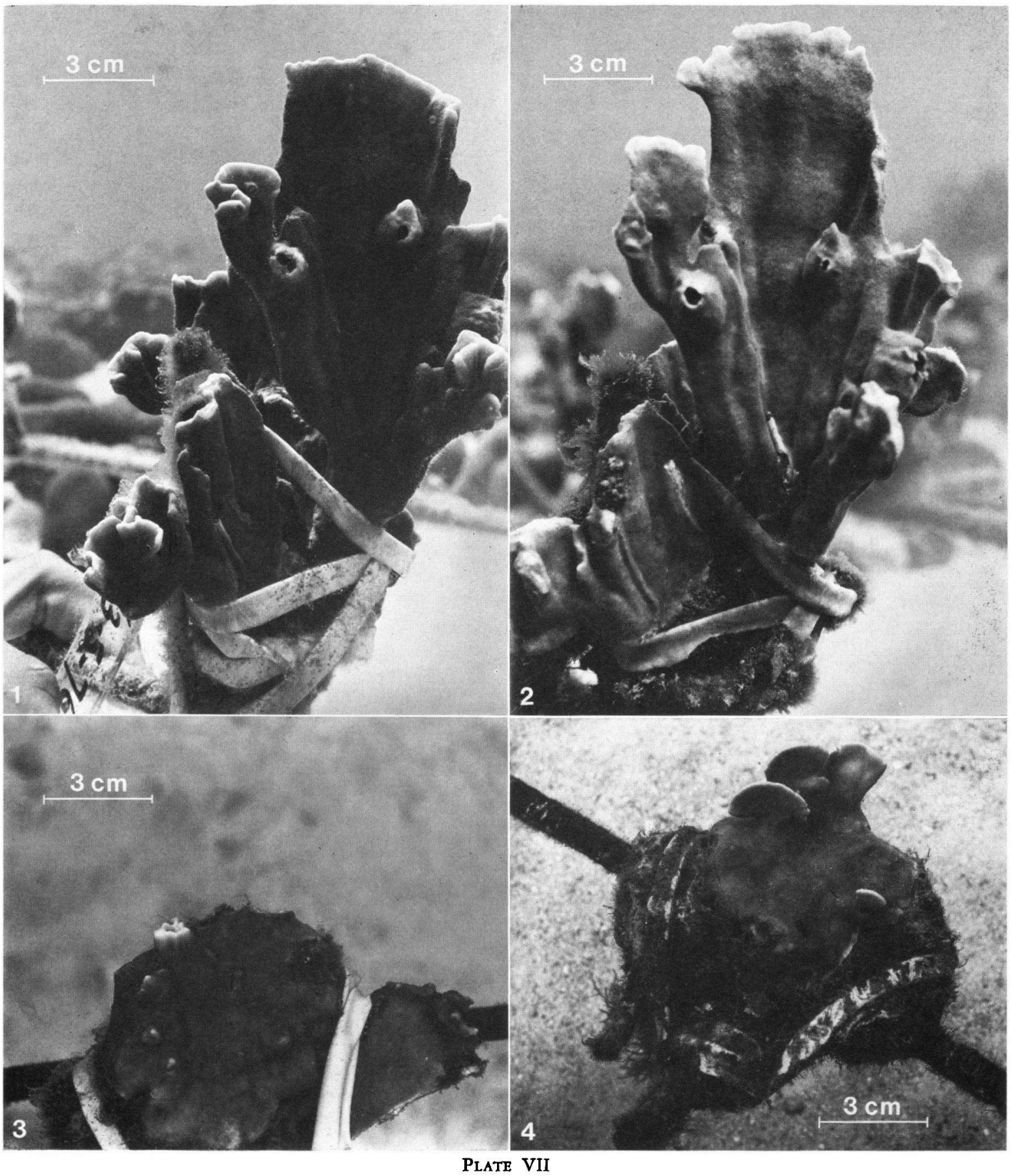

1, Boxwork colony, transplanted from $1 \mathrm{~m}$ to $5 \mathrm{~m}$, date: 18 May 1976; 2, same colony, date: 8 December 1976; 3, colony, incrusting dead coral, control colony of $5 \mathrm{~m}$, date: 29 March 1976; 4, same colony, date: 7 December 1976.

branching form started to resemble this form. From this it can be concluded that the growth form is induced by the factor depth (in which both water movement and light are included), and that the adaptability of Millepora to various con- ditions on the reef is very high.

To which extent Boschma (1948a) has taken into account the adaptibility of growth forms in Millepora may be apparent from the following. He stated $(: 71)$ : "There are a number of species 

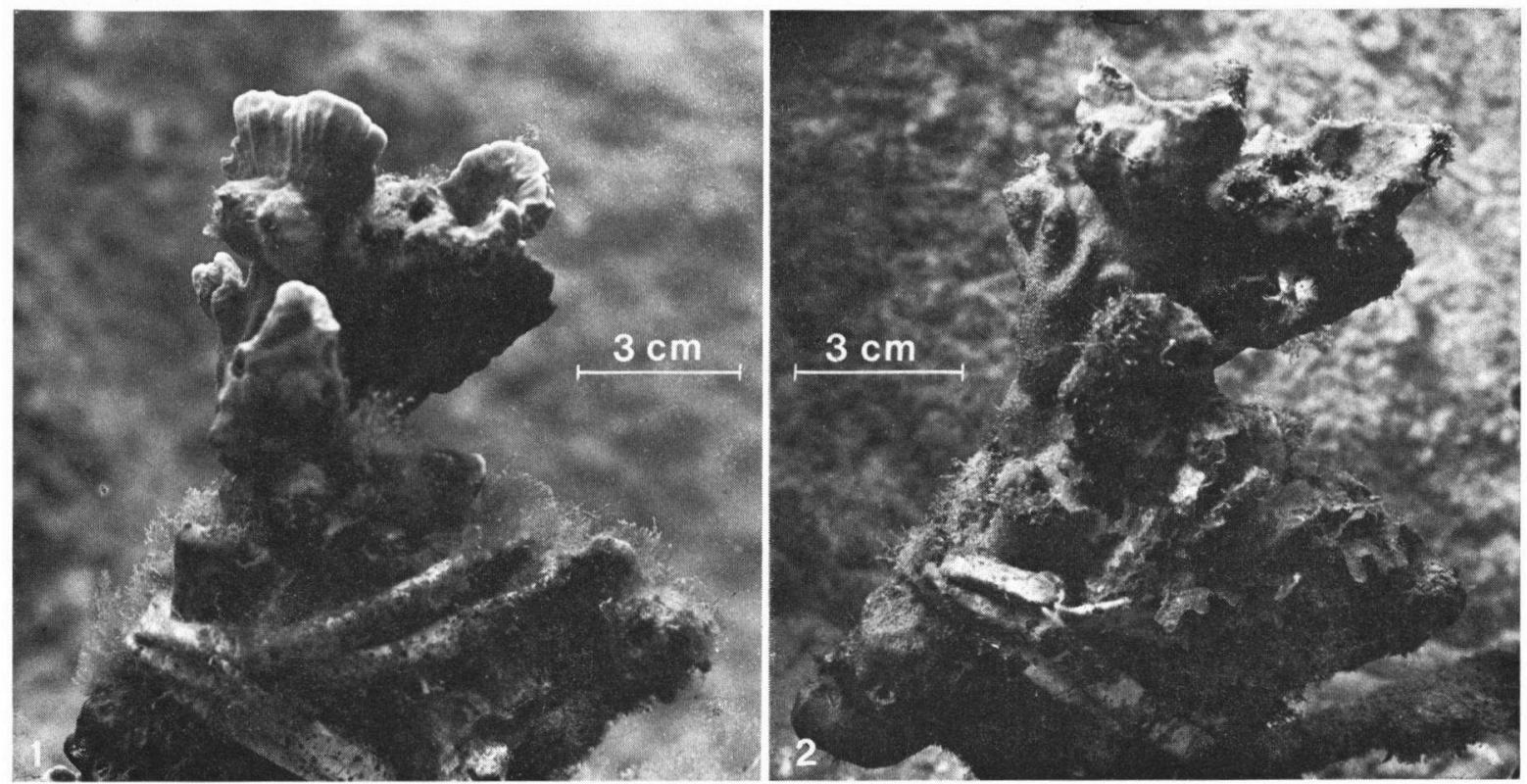

Plate VIII

1, Boxwork colony, transplanted from $1 \mathrm{~m}$ to station 6 (depth $5 \mathrm{~m}$ ), date: 30 March 1976; 2, same colony with ampullae: date: 10 December 1976.

in Millepora, each of which is so strongly variable that under the influence of external conditions it may assume a form which is more or less typical for another species." However, some pages earlier he stated (: 48): "But these changes in form, as they are caused by external influences, manifest themselves within certain limits. Every species of Millepora has its range of variation, but notwithstanding that it keeps certain characters of its growth form which as a rule are suffiently distinct to warrant a reliable specific identification." The results of the transplantation experiments are not in agreement with the last quoted statement, but indicate that the growth form of Millepora is more variable than Boschma supposed.

The following example shows that taxonomic treatment of growth forms is not consistent. In the Indo-Pacific as well as in the Atlantic region bladed Millepora corals occur in two growth forms: purely bladed and boxwork, but with many intermediate forms. Whereas the Indo-Pacific forms are considered as one species ( $M$. platyphylla), the Atlantic ones are treated as two different species ( $M$. complanata, $M$. squarrosa). In my opinion this is not justifiable, as long as identification is merely based on the growth form.
Certain Atlantic forms generally treated as $M$. squarrosa might however be the shallow-water form of $M$. complanata. The existence of many intermediate forms points in this direction. When I started the transplantation experiments I was convinced that the shallow boxwork form was $M$. squarrosa, for it fully agreed with the description of Boschma (1948a). Later, however, I studied the four specimens of this species in the Rijksmuseum van Natuurlijke Historie, Leiden (RMNH, coll. no. 8513, 8514, 8515 and 10557, the last specimen identified by Boschma), and they were clearly different from the boxwork forms found in Curaçao and Bonaire. The museum specimens differed in: general appearance, the ratio size gastropores/size dactylopores (the gastropores being at least twice as large as the dactylopores), the number of dactylopores surrounding each gastropore, the degree of isolation of the cyclosystems, formed by the gastropores and dactylopores, and finally in texture of the surface. The surface of the museum specimens was muck smoother than in the boxwork forms previously identified by me as $M$. squarrosa.

Concerning the occurrence of $M$. squarrosa, Boschma (1962) writes that this species is of a 
much rarer occurrence than $M$. alcicornis and $M$. complanata. Although $M$. squarrosa is of ficially known from Pernambuco (Brazil), Puerto Rico, Barbados (Boschma, 1962) and St. Eustasius (collection RMNH, det. Dr. J. van der Land), which means that it has a rather wide geographical distribution in the Western Atlantic region, only a few specimens have ever been observed. It might be that $M$. squarrosa does not even occur at Curaçao and Bonaire, and that the boxwork form is always erroneously considered to belong to this species. If this is the case $M$. squarrosa turns out to be a rather rare species, conform the observations of Boschma (1962), and all bladed (including the thin bladed boxwork, thick bladed boxwork and boxwork dwarf form) colonies treated in this paper should be identified as $M$. complanata, unless additional information about the above-mentioned characters points to a real specific status of the squarrosa form described in this paper.

A preliminary investigation of the sizes of the pores indicated that no differences between the boxwork and bladed forms exist, whereas these forms together differ significantly from the branching forms. Therefore a re-examination of the characters mentioned, including the size and shape of the ampullae (although not always present) seemed worth while after the present study. This may reveal characters which are of greater taxonomic significance than Boschma (1948a) supposed. The results of this study will be discussed in a future paper.

\section{ACKNOWLEDGEMENTS}

I wish to thank the staff of the Carmabi, Dr. I. Kristensen (director), Dr. H. A. M. de Kruijf and Dr. R. P. M. Bak for their hospitality and for providing housing, laboratory accommodation and diving facilities during $m y$ stay at the institute. Prof. Dr. J. H. Stock and Dr. H. A. M. de Kruijf were my supervisors and $I$ thank them for their help and suggestions. Thanks are also due to Mr. O. Frans, Mr. L. Maria, Mr. H. D. de Windt, Mr. F. Isabella and Mr. A. Tiel for their diving assistance and help with the underwater work and to Mr. C. Cardoze and Mr. J. D. Chirino for their technical assistance. Drs. J. C. den Hartog (Rijksmuseum van Natuurlijke Historie, Leiden) is acknowledged for the loan of specimens. I am greatly indebted to Dr. R. W. M. van Soest, Dr. S. Weinberg and Drs. E. R. Osieck for their suggestions and criticism of the manuscript. Finally $I$ wish to express my thanks to Mr. L. $\Lambda$. van der Laan for photographs of the corals and to Mr. J. Zaagman for assembling the plates.

\section{REFERENCES}

BAK, R. P. M., 1975. Ecological aspects of the distribution of reef corals in the Netherlands Antilles. Bijdr. Dierk., 45 (2): 181-190.

Boschм八, H., 1925. On the symbiosis of certain Bermudan coelenterates and zoöxanthellae. Proc. Am. Acad. Arts Sci., 55: 451-460.

- 1948a. The species problem in Millepora. Zool. Verh., Leiden, 1: 1-115, pls. I-XV.

- 1948b. Specific characters in Millepora. Proc. kon. Ned. Akad. Wet., 51: 818-824.

, 1949a. The ampullae of Millepora. Proc. kon. Ned. Akad. Wet., 52 (1): 3-15, pls. I-V.

,$- 1949 \mathrm{~b}$. Notes on specimens of the genus Millepora in the collection of the British Museum. Proc. zool. Soc. London, 119 (3): 661-672.

- 1950. Further notes on the ampullae of Millepora. Zool. Meded., Leiden, 31: 49-62, pls. I-II.

1961. Notes on Millepora braziliensis Verrill. Proc. kon. Ned. Akad. Wet., (C) 64: 292-297, pls. I-II.

1962. On Milleporine corals from Brazil. Proc. kon. Ned. Akad. Wet., (C) 65: 302-313, pls. I-VIII.

1966. On new species of Millepora from Mauritius with notes on the specific characters of $M$. exaesa. Proc. kon. Ned. Akad. Wet., (C) 69: 409-419, pls. I-II.

- 1968. The Milleporina and Stylasterina of the Israel South Red Sea expedition. Bull. Sea Fish. Res. Stn. Haifa, 49: 8-14.

Crossland, C., 1928. Notes on the ecology of the reefbuilders of Tahiti. Proc. zool. Soc. London, 1928: 717-735.

-, 1952. Madreporaria, Hydrocorallinea, Heliopora. Sci. Repts. Great Barrier Reef Exped., 1928-29, 6: 85-257.

Duchassaing De Fonbressin, P. \& J. MichelotTt, 1864. Supplément au mémoire sur les Coralliaires des Antilles. Mem. r. Acad. Sci. Torino, 2; 3: 97-206, pls. I-XI.

Fenninger, A. von \& G. Flajs, 1974. Zur Mikrostruktur rezenter und fossiler Hydrozoa. Biomineralisation, 7: $69-100$, pls. I-X.

GoreaU, T. F., 1959. The ecology of Jamaican coral reefs. I. Species composition and zonation. Ecology, 40: 76-90.

-, 1963. Calcium carbonate deposition by coralline algae and corals in relation to their roles as reef builders. Ann. N.Y. Acad. Sci., 109: 127-167.

Goreau, T. F. \& N. I. Gorenu, 1959. The physiology of skeleton formation in corals. II. Calcium deposition by hermatypic corals under various conditions in the reef. Biol. Bull., 117: 239-250.

Hickson, S. J., 1898a. On the species of the genus Millepora: a preliminary communication. Proc. zool. Soc. London, 1898: 246-257.

- 1898b. Notes on the collection of specimens of the genus Millepora obtained by Mr. Stanley Gardiner at Funafuti and Rotuma. Proc. zool. Soc. London, 1898: 828-833.

KRUIJP, H. A. M. DE, 1975. General morphology and behaviour of gastrozoids and dactylozoids in two species of Millepora (Milleporina, Coelenterata). Mar. behav. Physiol., 3: 181-192.

MANTEN, A. A., 1960. De groeivorm van kotalen als milieuindicatoren. Grondboor Hamer, 5: 145-165. (Rectification, 6: 203).

Mattraw, H. C., JR., 1969. Variations of Millepora alcicor- 
nis on the Bermuda platform. Bermuda biol. Stat. spec. Publs., 6: 29-38.

MERgNeR, H., 1971. Structure, ecology and zonation of Red Sea Reefs (in comparison with South Indian and Jamaican Reefs). Symp. zool. Soc. London, 28: 141-161.

$\longrightarrow$, 1977. Hydroids as indicator species for ecological parameters in Caribbean and Red Sea coral reefs. Proc. 3rd int. Coral Reef Symp., 1: 119-126.

Milliman, J. D., 1969. Four southwestern Caribbean atolls: Courtown Cays, Albuquerque Cays, Roncador Bank, Serrana Bank. Atoll Res. Bull., 129: 1-26.

$\longrightarrow$, 1973. Caribbean coral reefs. In: O. A. Jones \& $R$. EDEAN, eds., Biology and geology of coral reefs, 1: 1-51.

MOSELEY, H. N., 1877. On the structure of a species of Millepora occurring at Tahiti, Society Island. Phil. Trans, r. Soc. London, 167: 117-135.

Roos, P. J., 1964. The distribution of reef corals in Curaçao. Stud. Fauna Curaçao, 20: 1.51, pls. I-XIII.

- 1967. Growth and occurrence of the reef coral Porites astreoides Lamarck in relation to submarine radiance distribution: 1-72. (Thesis, Univ, Amsterdam) (Elinkwijk, Utrecht).

- 1971. The shallow-water stony corals of the Netherlands Antilles. Stud. Fauna Curaçao, 37: 1.108, pls. I-LIII.

StEARN, C. W. \& R. RIDING, 1973. Forms of the hydrozoan Millepora on a Recent coral reef. Lethaia, 6: 187-200.
Stephenson, T. A. \& A. Stephenson, 1933. Growth and asexual reproduction in corals. Sci. Repts. Great Barrier Reef Exped., 1928-29, 3 (7): 167-217, pls. I.X.

STODDART, D. R., 1969. Ecology and morphology of Recent coral reefs. Biol. Rev., 44 (4): 433-498.

STRömGreN, T., 1975. Skeleton growth of the hydrocoral Millepora complanata Lamarck in relation to light. Limnology Oceanogr., 21 (1): 156-160.

Vaughan, T. W. \& J. W. Wells, 1943. Revision of the suborders, families and genera of the Scleractinia. Spec. Pap. geol. Soc. Am, 44: 1-363, pls. I-LI.

Velimirov, B., 1974. Orientiertes Wachstum bei Millepora dichotoma (Hydrozoa). Helgoländ. wiss. Meeresunters., 26: $18-26$.

WAHLE, C. M., 1980. Detection, pursuit, and overgrowth of tropical gorgonians by milleporid hydrocorals: Perseus and Medusa revisited. Science, 209: 689-692.

WoOD-Jones, F, 1907. On the growth forms and supposed species in corals. Proc. zool. Soc. London, 1907: 518-556.

WiJSMan-Best, M., 1972. Systematics and ecology of New Caledonian Faviinae (Coelenterata-Scleractinia). Bijdr. Dierk., 42 (1): 1-91, pls. I-XIV.

- 1974. Habitat-induced modifications of reef corals (Faviidae) and its consequences for taxonomy. Proc. 2nd int. Coral Reef Symp.: 217-228.

YoNGE, C. M., 1963. The biology of coral reefs. Adv. mar. Biol., 1: 209-260. 